\title{
EFFECT OF COMPETITION ON THE INTERACTION BETWEEN MAIZE AND WEED EXPOSED TO WATER DEFICIENCY ${ }^{1}$
}

\author{
CLAUDIA DAIANNY MELO FREITAS ${ }^{2}$, FERNANDO SARMENTO DE OLIVEIRA ${ }^{3 *}$, HÉLIDA CAMPOS DE \\ MESQUITA $^{4}$, ALANNA OLIVEIRA CORTEZ ${ }^{5}$, MARIA ALICE FORMIGA PORTO ${ }^{3}$, DANIEL VALADÃO SILVA ${ }^{3}$
}

\begin{abstract}
The ability of plants to adapt to water deficient conditions in soil is directly related to the competitive ability of each species. The objective of the present study was to evaluate the effects of water deficiency and interspecific competition on the growth components of maize (Zea mays), brachiaria (Urochloa decumbens), and hairy beggarticks (Bidens pilosa $\mathrm{L}$ ). The experimental design was in randomized blocks, with eight replications. The treatments were arranged in a $5 \times 2$ factorial design, with the first factor corresponding to the different competitive arrangements among species (maize $+U$. decumbens, maize $+B$. pilosa, maize without competition, $U$. decumbens without competition, and B. pilosa without competition). The second factor constituted two water regimes (daily irrigation and water deficit). The soil water deficient condition strongly decreased maize plant growth; however, it had little or no effect on the growth of weeds $U$. decumbens and $B$. pilosa. Interspecific competition decreased the growth of maize plants and $U$. decumbens, and intensified the negative effects of water deficiency on these species. Interspecific competition and water deficiency also decreased the $\mathrm{N}, \mathrm{P}$, and $\mathrm{K}$ content in maize plants, which contributed to the effects on plant growth. $U$. decumbens was more competitive with maize compared to B. pilosa.
\end{abstract}

Keywords: Zea mays. Bidens pilosa. Urochloa decumbens. Growth. Water stress.

\section{EFEITO DA COMPETIÇÃO NA INTERAÇÃO ENTRE MILHO E PLANTAS DANINHAS EXPOSTAS À DEFICIÊNCIA HÍDRICA}

\begin{abstract}
RESUMO - A capacidade de adaptação das plantas a condição de deficiência hídrica no solo está diretamente relacionada à habilidade competitiva por água de cada espécie. O objetivo do presente estudo foi avaliar os efeitos da deficiência hídrica e da competição interespecífica nos componentes de crescimento de milho, Urochloa decumbens e Bidens pilosa. O delineamento experimental foi em blocos casualizados, com 8 repetições. Os tratamentos foram arranjados em fatorial $5 \times 2$, com o primeiro fator constituído dos arranjos das espécies (milho $+U$. decumbens; milho + B. pilosa; milho, U. decumbens e B. pilosa sem competição) e o segundo fator composto por dois regimes hídricos (irrigação diária e déficit hídrico). $\mathrm{O}$ déficit hídrico no solo reduziu fortemente o crescimento das plantas de milho, no entanto, teve pouco ou nenhum efeito sobre o crescimento das plantas daninhas $U$. decumbens e B. pilosa. A competição interespecífica reduziu o crescimento das plantas de milho e $U$. decumbens, e intensificou os efeitos negativos do déficit hídrico nestas espécies. A competição interespecífica e o déficit hídrico também reduziram os conteúdos de $\mathrm{N}, \mathrm{P}$ e $\mathrm{K}$ nas plantas de milho, o que também contribui para os efeitos no crescimento das plantas. $U$. decumbens foi mais competitivo com o milho em comparação com B. Pilosa.
\end{abstract}

Palavras-chave: Zea mays. Bidens pilosa. Urochloa decumbens. Crescimento. Estresse hídrico.

\footnotetext{
${ }^{*}$ Corresponding author

${ }^{1}$ Received for publication in 01/19/2019; accepted in 05/06/2019.

Paper extracted from the master dissertation of the first author.

${ }^{2}$ Master in Agronomy/Fitotecnia, Universidade Federal Rural do Semi-Árido, Mossoró, RN, Brazil; claudiamelof@hotmail.com - ORCID: 0000-0001-5243-5071.

${ }^{3}$ Department of Agronomic and Forest Sciences, Universidade Federal Rural do Semi-Árido, Mossoró, RN, Brazil; fernandosarmentho@hotmail.com - ORCID: 0000-0002-4019-5899, mariaalice6@hotmail.com - ORCID: 0000-0001-7299-2844, daniel.valadao@ufersa.edu.br - ORCID: 0000-0003-0644-2849.

${ }^{4}$ Instituto Federal de Ciência e Tecnologia, Apodi, RN, Brazil; helidamesquita.ifrn@gmail.com - ORCID: 0000-0003-0357-6841.

${ }^{5}$ Master in Environment, Technology and Society, Universidade Federal Rural do Semi-Árido, Mossoró, RN, Brazil; alannacortez23@gmail.com - ORCID: 0000-0001-6657-0442.
} 


\section{INTRODUCTION}

Maize (Zea mays L.) is a crop of great economic importance because it is used as human and animal food, and to produce biofuels. It is cultivated in several countries, with the United States, China, and Brazil producing more than $65 \%$ worldwide (USDA, 2017). In cultivation systems, production factors are carefully controlled to reduce possible biotic and abiotic stresses that might reduce crop yields (CUSTODIO et al., 2016).

Water deficiency is one of the main factors that is responsible for decreases of maize crop yield because it affects the water relations of the plants, reducing growth and development, and consequently crop productivity (SALES et al., 2016). It is estimated that $90 \%$ of maize yield can be affected by water deficiency (NESMITH; RITCHIE, 1992).

In addition to productivity losses, water deficiency might shorten the grain formation period and interfere with ovarian development, increasing the number of aborted grains (MARWEIN et al., 2017). Water stress can also alter the ratio of root/ shoot biomass and reduce the total dry mass production (GHEYSARI et al., 2017).

Water deficiency may limit the availability of other resources for plants, such as absorption reduction and nutrient accumulation (HU; SCHMIDHALER, 2005), owing to the reduction of root growth, and the fact that water is the vehicle whereby mineral nutrients move from the soil solution to the roots of the plant (MARSCHNER, 1995; GESSLER; SCHAUB; MCDOWELL, 2017).

Water deficiency is caused by a scarcity of water that is required for the full development of plants. Factors such as soil texture, organic matter content, and competition with other plants can reduce the amount of water in the soil, thus aggravating the effects of water deficiency in plants. Among these factors, competition with weeds can greatly reduce the availability of water to crops, which interferes with the development and productivity of maize by up to $85 \%$ (GANTOLI; AYALA; GERHARDS, 2013). The competition between crops and weeds occurs when resources, such as water, light, and nutrients, are limiting and the losses caused by this competition vary based on the competitive capacity of the species involved (SILVA et al., 2013).

The intensity of water competition depends on the survival mechanisms that each species develops under water deficit conditions (OLIVEIRA et al., 2018). Weeds such as brachiaria (Urochloa decumbens) and hairy beggarticks (Bidens pilosa) have high water-use efficiency characteristics (ASPIAZÚ et al., 2010). These species can grow and develop under semiarid conditions (MASHINGAIDZE et al., 2012; FLORINDO et al., 2014) because they have different resistance mechanisms to water deficiency (OLIVEIRA et al.,
2018), can change the proportion of biomass between roots and aerial parts, and have different competitive capacities (FOTELLI et al., 2001). Knowledge regarding these physiological mechanisms is essential for understanding the interactions between maize and weeds, and the correct use of management strategies to minimize competition for water in agroecosystems. Therefore, the objective of the present study was to evaluate the effects of water deficiency and interspecific competition on the growth components of maize, $U$. decumbens and B. pilosa.

\section{MATERIAL AND METHODS}

The experiment was undertaken in a greenhouse with geographical coordinates $05^{\circ} 11^{\prime} 15^{\prime \prime}$ S, $37^{\circ} 20^{\prime} 39^{\prime \prime} \mathrm{W}$. The experimental unit was a plastic vessel with a volume capacity of $8.5 \mathrm{dm}^{3}$, filled with sandy clay loam that was classified as Cambisol (EMBRAPA, 2018). The same was collected from the $0-20 \mathrm{~cm}$ surface layer, and based on physicochemical analysis showed the following characteristics: $\mathrm{pH}$ (water) $=7.2 ; \mathrm{MO}=8.10 \mathrm{~g} \mathrm{~kg}^{-1}$; $\mathrm{P}=2.2 \mathrm{mg} \mathrm{dm}^{-3} ; \mathrm{K}=434.6 \mathrm{mg} \mathrm{dm}{ }^{-3} ; \mathrm{Na}=49.3 \mathrm{mg}$ $\mathrm{dm}^{-3}$; and $\mathrm{Ca} ; \mathrm{Mg} ; \mathrm{Al} ; \mathrm{H}+\mathrm{Al}$; and effective $\mathrm{CTC}=$ $11.30 ; 2.10 ; 0.00 ; 0.00$; and $14.73 \mathrm{cmol}_{\mathrm{c}} \mathrm{dm}^{-3}$, respectively; and sand, silt, and clay $=0.57,0.10$, and $0.33 \mathrm{~kg} \mathrm{~kg}^{-1}$, respectively. Fertilization and cultivation were performed based on the needs of the crop.

The experimental design was that of completely randomized blocks. The treatments were arranged in a factorial $5 \times 2$ design, with eight replications. The first factor consisted of different competitive arrangements among species (maize + $U$. decumbens, maize $+B$. pilosa, maize without competition, $U$. decumbens without competition, and B. pilosa without competition). The second factor constituted two water regimes (daily irrigated and water deficiency).

The maize hybrid AG-1051, brachiaria ( $U$. decumbens), and hairy beggarticks (B. pilosa) were included in the study. The seeds underwent preliminary germination and emergency tests to establish the ideal seeding period for the simultaneous emergence of these species. Maize seeds and weeds were sown in the center and border of each experimental unit, respectively. Thinning was performed 5 days after plant emergence, leaving only one plant of each species.

Irrigations were performed daily to maintain moisture near field capacity $(70-80 \%)$. The volume of water applied to each vessel was calculated by the difference between the vessel weight in its field capacity and the weight at the end of each day (CARVALHO et al., 2005).

When maize plants had grown their third expanded leaf (phenological stage V3), the 
imposition of water regimes (daily irrigation and water deficit) was initiated. The irrigation treatment plants continued to receive daily irrigation as described, and those in the water deficit treatment had their irrigation totally suspended. The duration of the water deficit was maintained until the rate of assimilation of $\mathrm{CO}_{2}(A)$ of maize plants reached values close to zero, which occurred after 5 days of irrigation suspension. From that moment, irrigation was reestablished, maintaining the humidity close to the field capacity. $A$ was measured with the aid of an infrared gas analyzer (IRGA, portable model LI6400, LI-COR Biosciences).

After the recovery of the $A$ of plants submitted to the water deficit treatment, the following were measured: plant height $(\mathrm{PH} ; \mathrm{cm})$, determined from the soil to the insertion of the last leaf; leaf area (LA; $\mathrm{cm}^{2}$ plant $\left.^{-1}\right)$, obtained by the corrected disk method (SOUZA et al., 2012); and specific leaf area (SLA; $\left.\mathrm{cm}^{2} \mathrm{~g}^{-1}\right)$, ratio between dry leaf mass and LA. The plants were then washed lightly with distilled water and fractionated into aerial parts and roots, which were packed in paper bags and placed in a forced air circulation oven at a temperature of $65 \pm 1^{\circ} \mathrm{C}$ until a constant mass was reached. Then, each fraction was weighed on an analytical balance to obtain the dry mass $\left(\mathrm{g}\right.$ plant $\left.{ }^{-1}\right)$. The dried maize material was milled in a Wiley type mill, homogenized, and stored in an airtight container. Samples of this material were used to determine the nitrogen $(\mathrm{N})$, phosphorus $(\mathrm{P})$, and potassium $(\mathrm{K})$ contents in the different compartments (leaf, stem, and root) of the maize plants. The $\mathrm{N}$ content was determined by the Kjeldahl method in the sulfur digestion extract. After nitric-perchloric digestion, the contents of $\mathrm{P}$ were determined by colorimetry and $\mathrm{K}$ values by flame photometry (MALAVOLTA; VITTI; OLIVEIRA, 1997). From the dry mass of each fraction and their respective nutrient contents, the macronutrient content was calculated.

The data were submitted to analysis of variance using the $F$ test $(p \leq 0.05)$ and, when significant, the averages were compared by Tukey's test at 5\% probability level. The statistical software used was SISVAR ${ }^{\circledR} 5.6$.

\section{RESULTS AND DISCUSSION}

\section{Growth of maize under conditions of water deficit} and competition with $U$. decumbens and $B$. pilosa

There was interaction between the water deficit factors and competitive interaction arrangements between the species for $\mathrm{PH}$, LA, and SLA. Water deficiency decreased PH, LA, and SLA of maize plants cultivated alone and in competition with $U$. decumbens and B. pilosa (Figure 1).
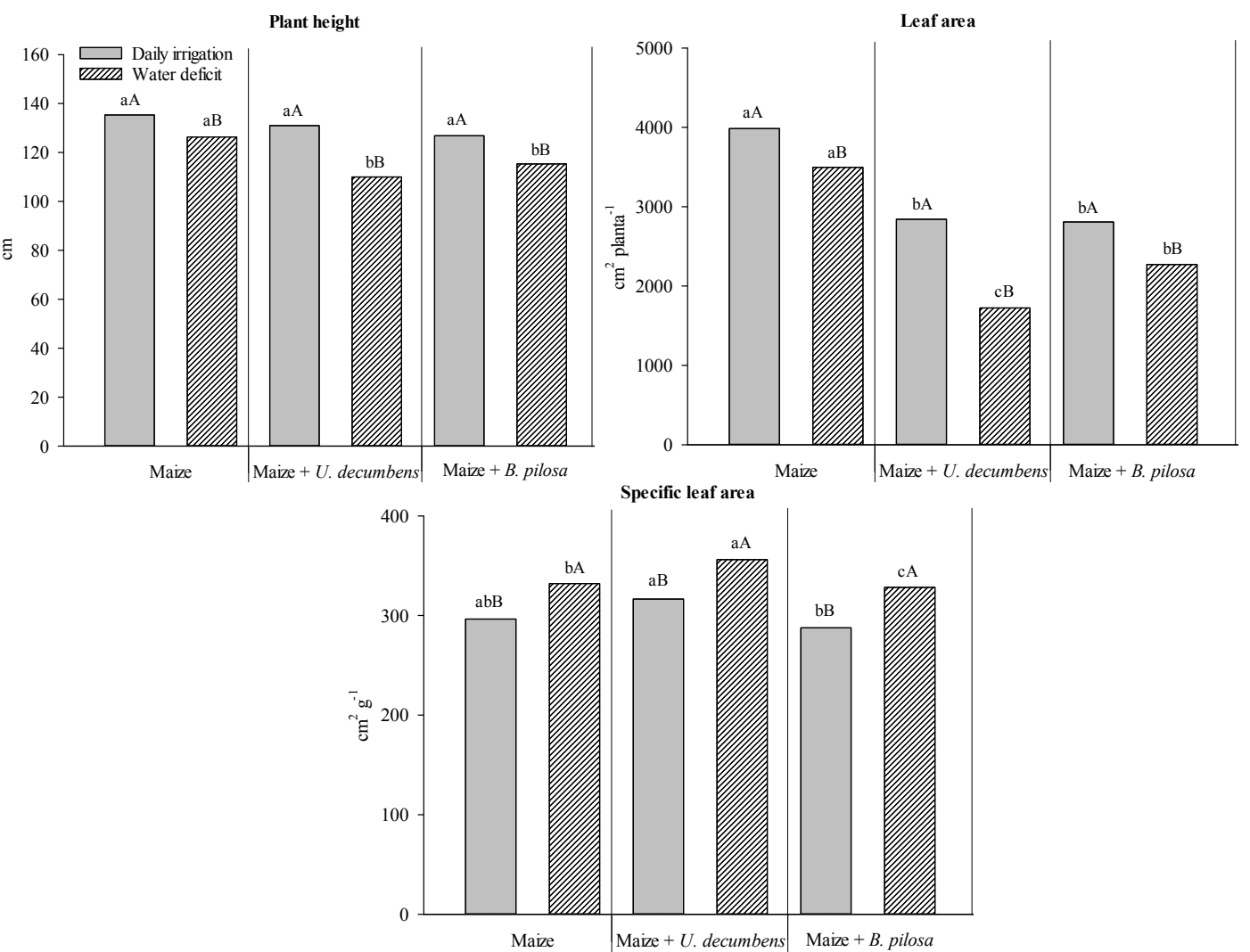

Figure 1. Plant height (PH), leaf area (LA) and specific leaf area (SLA) of maize in monoculture and competition with $U$. decumbens and B. pilosa under water deficit or not. Different letters indicate difference ( $\mathrm{p} \leq 0.05$; Tukey's test): lowercase among types of arrangement between plants; upper case between the two water regimes. 
This reduction in PH and LA is possibly due to the lower turgor pressure of the growing cells (FENG et al., 2016). Turgor pressure is the mechanism that is responsible for the expansion of plant cells. As maize plants lose water via transpiration under conditions of low water availability in the soil, the turgor pressure is reduced owing to the smaller amount of water inside the cell (FENG et al., 2016).

The presence of $B$. pilosa and $U$. decumbens plants together with the maize plants reduced the LA of the crop compared to maize cultivated alone, under irrigated conditions (Figure 1). Under water deficit conditions, there was a greater reduction of the LA of maize cultivated with $U$. decumbens compared to the other treatments (Figure 1). Therefore, there was competition for growth resources between the maize crop and B. pilosa and $U$. decumbens weed plants. Even when the amount of water in the soil was maintained near field capacity, competition with weeds affected the LA of maize.

$U$. decumbens plants presented greater aggressiveness in relation to $B$. pilosa under conditions of low water availability, and promoted a greater reduction in the LA of maize plants. Similar to maize, $U$. decumbens has $\mathrm{C} 4$ metabolism and, under conditions of water limitation, can allow photosynthesis to function and promote its growth even with less water compared to that of B. pilosa (GUENNI; BARUCH; MARIN, 2004). This is possible because, first, C4 plants have a higher efficiency of water use, mainly owing to their control of the loss of water to carbon gain in leaves (GHANNOUM; VON CAEMMERER; CONROY, 2002); and, second, these plants do not have detectable photorespiration (loss of carbon) because of their leaf anatomy (WALKER et al., 2016). These characteristics contribute to the higher efficiency of these plants under stress conditions.

The water deficit treatment increased the SLA of maize grown alone and in competition with $U$. decumbens and B. pilosa (Figure 1). Analyzing the effect of competition on the SLA, maize plants in competition with $U$. decumbens had higher values compared to the other treatments. SLA is an indicator of leaf thickness. An increase of this parameter in plants under water deficit and/or competition is not a common situation, and may be a strategy of the plant to maximize photosynthesis This is because the thicker leaves generally have a higher density of chlorophyll and proteins per unit area of LA and, therefore, have a greater photosynthetic capacity than that of thinner leaves (LIU; STÜTZEL, 2004).

The root dry mass (RDM), shoot dry mass (SDM) and total dry mass (TDM) of maize plants were negatively influenced by the water deficiency and competition with weeds treatments (Figure 2). The reduction of dry mass in plants frequently occurs under conditions of water deficiency and is related to the reduction of turgescence in plant cells (TAIZ et al., 2017). Under conditions of low water availability, plants normally tend to close their stomata to minimize water loss via transpiration. This adaptive mechanism allows the survival of the plants during the period of water deficiency in the soil for a longer period; however, it results in subsistence (limited) growth, which is lower than what the plants experience under normal conditions (BASU et al., 2016).

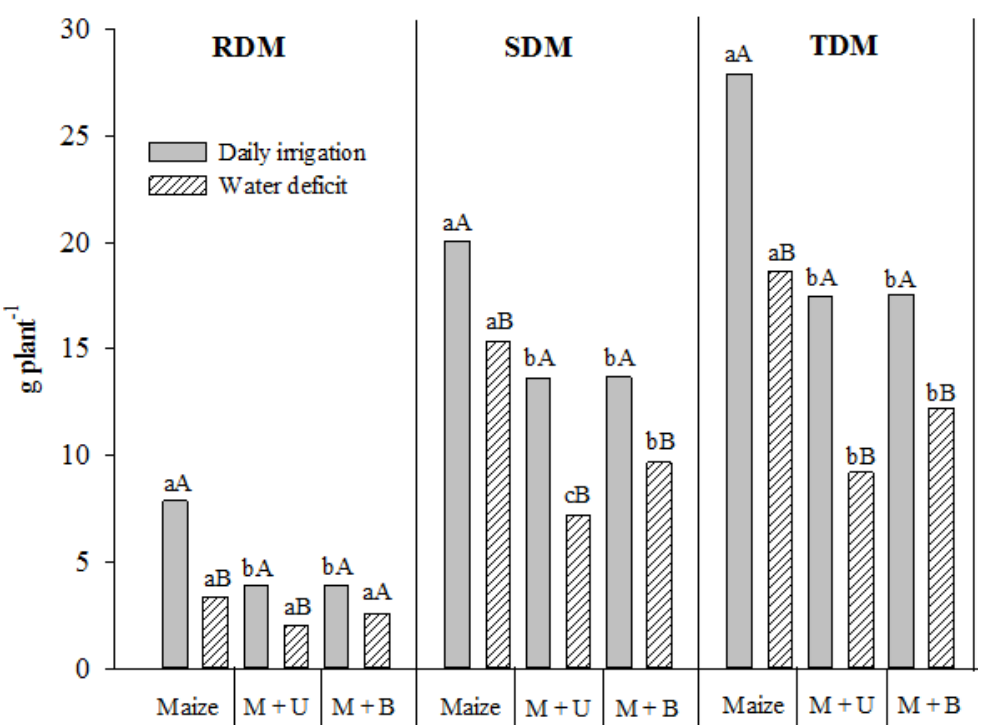

Figure 2. Root dry mass (RDM), shoot (SDM) and total (TDM) of maize in monoculture and competition with $U$. decumbens and $B$. pilosa, under water deficit conditions or not. $\mathrm{M}=$ Maize; $\mathrm{U}=U$. decumbens; $\mathrm{B}=B$. pilosa. Different letters indicate difference ( $\mathrm{p} \leq 0.05$; Tukey test): lowercase among types of arrangement between plants; upper case between the two water regimes. 
Maize plants, under water deficit conditions, cultivated in competition with $U$. decumbens showed a larger reduction in SDM and TDM compared to the other treatments (Figure 2). This may have been a reflection of the greater aggressiveness of $U$. decumbens in competing with the maize crop, resulting in lower LA and photoassimilated synthesis in the maize plant. The lowest LA that was found in maize when cultivated in conjunction with $U$. decumbens correlated with RDM data, which also showed a reduction due to weed interference.

In general, the results suggest that the effects of water restrictions may have induced stomatal closure of maize plants. Maize plants, when under conditions of a lack of water, reduce stomatal opening to reduce excessive water loss (RAJCAN; SWANTON, 2001). However, this reduces stomatal conductance and photosynthesis due to lower absorption of $\mathrm{CO}_{2}$ in the mesophyll; thus, reducing the ability of maize to accumulate biomass in its tissues (TAIZ et al.,
2017).

Macronutrient content in maize subjected to water deficiency and competition with $U$. decumbens and $B$. pilosa

There was an isolated effect of water deficiency and competition factors for $\mathrm{N}, \mathrm{P}$, and $\mathrm{K}$ content in the different organs of maize plants (Table 1). Lower $\mathrm{N}, \mathrm{P}$, and $\mathrm{K}$ contents were observed in the different compartments (leaf, stem, root, and total) of the plants in the competition treatments, mainly for the $U$. decumbens species, except for the root $\mathrm{P}$ content that was not altered. As root trapping contributes strongly to $\mathrm{P}$ uptake in plants, it is possible that the initial rapid maize growth may have contributed to the roots occupying more soil volume, allowing an advantage over the weeds in competition for $\mathrm{P}$ (MATOS et al., 2019).

Table 1. Average contents of nitrogen $(\mathrm{N})$, phosphorus $(\mathrm{P})$ and potassium $(\mathrm{K})$ in leaf, stem, root and total of maize in monoculture and in competition with $U$. decumbens and $B$. pilosa under irrigated and water deficit regimes.

\begin{tabular}{|c|c|c|c|c|}
\hline \multirow{2}{*}{ Species } & \multicolumn{4}{|c|}{$\mathrm{N}\left(\mathrm{mg}\right.$ plant $\left.^{-1}\right)$} \\
\hline & Leaf & Stem & Root & Total \\
\hline Maize & $260.03 a$ & $98.17 \mathrm{a}$ & $75.94 a$ & $434.15 \mathrm{a}$ \\
\hline$M+U$ & $144.55 \mathrm{c}$ & $50.87 \mathrm{~b}$ & $30.22 \mathrm{~b}$ & $225.65 \mathrm{c}$ \\
\hline$M+B$ & $205.04 b$ & $62.75 \mathrm{~b}$ & $41.65 \mathrm{ab}$ & $309.46 \mathrm{~b}$ \\
\hline CV (\%) & 14.79 & 16.44 & 29.31 & 13.93 \\
\hline \multirow{2}{*}{ Species } & \multicolumn{4}{|c|}{$\mathrm{P}\left(\mathrm{mg} \mathrm{plant}^{-1}\right)$} \\
\hline & Leaf & Stem & Root & Total \\
\hline Maize & $53.75 a$ & $23.20 \mathrm{a}$ & $16.22 \mathrm{a}$ & $93.18 \mathrm{a}$ \\
\hline $\mathrm{M}+\mathrm{U}$ & $28.0 \mathrm{~b}$ & $13.19 \mathrm{~b}$ & $9.06 \mathrm{a}$ & $50.25 \mathrm{~b}$ \\
\hline$M+B$ & $39.48 \mathrm{ab}$ & $15.58 \mathrm{~b}$ & $10.34 \mathrm{a}$ & $65.39 \mathrm{~b}$ \\
\hline CV (\%) & 25.42 & 17.94 & 24.50 & 21.91 \\
\hline \multirow{2}{*}{ Species } & \multicolumn{4}{|c|}{$\mathrm{K}\left(\right.$ mg plant $\left.{ }^{-1}\right)$} \\
\hline & Leaf & Stem & Root & Total \\
\hline Maize & $351.77 \mathrm{a}$ & $222.96 \mathrm{a}$ & $69.04 a$ & $643.77 \mathrm{a}$ \\
\hline$M+U$ & $185.65 \mathrm{c}$ & $129.41 \mathrm{~b}$ & $32.52 \mathrm{~b}$ & $347.60 \mathrm{c}$ \\
\hline$M+B$ & $249.0 \mathrm{~b}$ & $182.40 \mathrm{a}$ & $34.22 \mathrm{~b}$ & $465.62 \mathrm{~b}$ \\
\hline CV $(\%)$ & 14.73 & 16.43 & 15.80 & 13.68 \\
\hline \multirow{2}{*}{ Regimes } & \multicolumn{4}{|c|}{$\mathrm{N}\left(\mathrm{mg} \mathrm{plant}^{-1}\right)$} \\
\hline & Leaf & Stem & Root & Total \\
\hline Irrigated & $224.91 \mathrm{a}$ & $76.58 \mathrm{a}$ & $62.32 \mathrm{a}$ & $363.81 \mathrm{a}$ \\
\hline WD & $181.51 \mathrm{~b}$ & $64.63 \mathrm{a}$ & $36.22 \mathrm{~b}$ & $282.36 \mathrm{~b}$ \\
\hline CV (\%) & 14.79 & 16.44 & 29.31 & 13.93 \\
\hline \multirow{2}{*}{ Regimes } & \multicolumn{4}{|c|}{$\mathrm{P}\left(\mathrm{mg}\right.$ plant $\left.^{-1}\right)$} \\
\hline & Leaf & Stem & Root & Total \\
\hline Irrigated & $48.17 \mathrm{a}$ & $20.38 \mathrm{a}$ & $15.48 \mathrm{a}$ & $84.02 \mathrm{a}$ \\
\hline WD & $32.66 \mathrm{~b}$ & $14.27 \mathrm{~b}$ & $8.27 \mathrm{~b}$ & $55.20 \mathrm{~b}$ \\
\hline CV (\%) & 25.42 & 17.94 & 24.50 & 21.91 \\
\hline \multirow{2}{*}{ Regimes } & \multicolumn{4}{|c|}{$\mathrm{K}\left(\mathrm{mg} \mathrm{plant}^{-1}\right)$} \\
\hline & Leaf & Stem & Root & Total \\
\hline Irrigated & $293.33 \mathrm{a}$ & $200.99 a$ & $61.14 \mathrm{a}$ & $555.47 \mathrm{a}$ \\
\hline WD & $230.95 b$ & $155.53 b$ & $29.38 b$ & $415.86 \mathrm{~b}$ \\
\hline CV (\%) & 14.73 & 16.43 & 15.80 & 13.68 \\
\hline
\end{tabular}

$\mathrm{M}=$ Maize; $\mathrm{U}=$ Urochloa decumbens; $\mathrm{B}=$ Bidens pilosa; $\mathrm{CV}=$ Coefficient of variation; $\mathrm{WD}=$ Water deficit; Averages followed by the same letter do not differ for each variable at the $5 \%$ probability level by the Tukey's test. 
As for the effect of water regimes (Table 1), apart from the stem $\mathrm{N}$ content, the plants under water deficit conditions had the lowest $\mathrm{N}, \mathrm{P}$, and $\mathrm{K}$ contents in the different compartments evaluated.

Lower average content of $\mathrm{N}, \mathrm{P}$, and $\mathrm{K}$ in maize cultivated with $U$. decumbens indicates that this weed has a higher competitive capacity than $B$. pilosa. Crops and weeds share the same resources below and aboveground (KAUR; KAUR; CHAUHAN, 2018). Water and nutrients are the main factors for which organisms compete, and usually weeds take advantage of this competition, reducing the availability of these resources in the soil, which may have resulted in lower absorption and accumulation of nutrients in maize (SCHENK, 2006; KAUR; KAUR; CHAUHAN, 2018).

The reduction in the $\mathrm{N}, \mathrm{P}$, and $\mathrm{K}$ contents in plants under water deficient conditions may be a reflection of several factors, such as the reduction of plant growth (GESSLER; SCHAUB; MCDOWELL, 2017); the reduction of the transport of ions to the roots, either by diffusion (P and $\mathrm{K})$ or mass flow $(\mathrm{N})$, which are processes that depend on soil moisture content (HU; SCHMIDHALTER, 2005); and the negative effects of water stress on the limitation of root growth and its nutrient absorption and translocation capacity (MARSCHNER, 1995).

\section{Growth of $\boldsymbol{U}$. decumbens under water deficiency and maize competition conditions}

Water deficiency decreased the PH and LA of U. decumbens when cultured alone (Figure 3). However, this effect was not observed in $U$. decumbens plants grown together with maize. The effects of water deficiency and maize competition did not influence SLA.

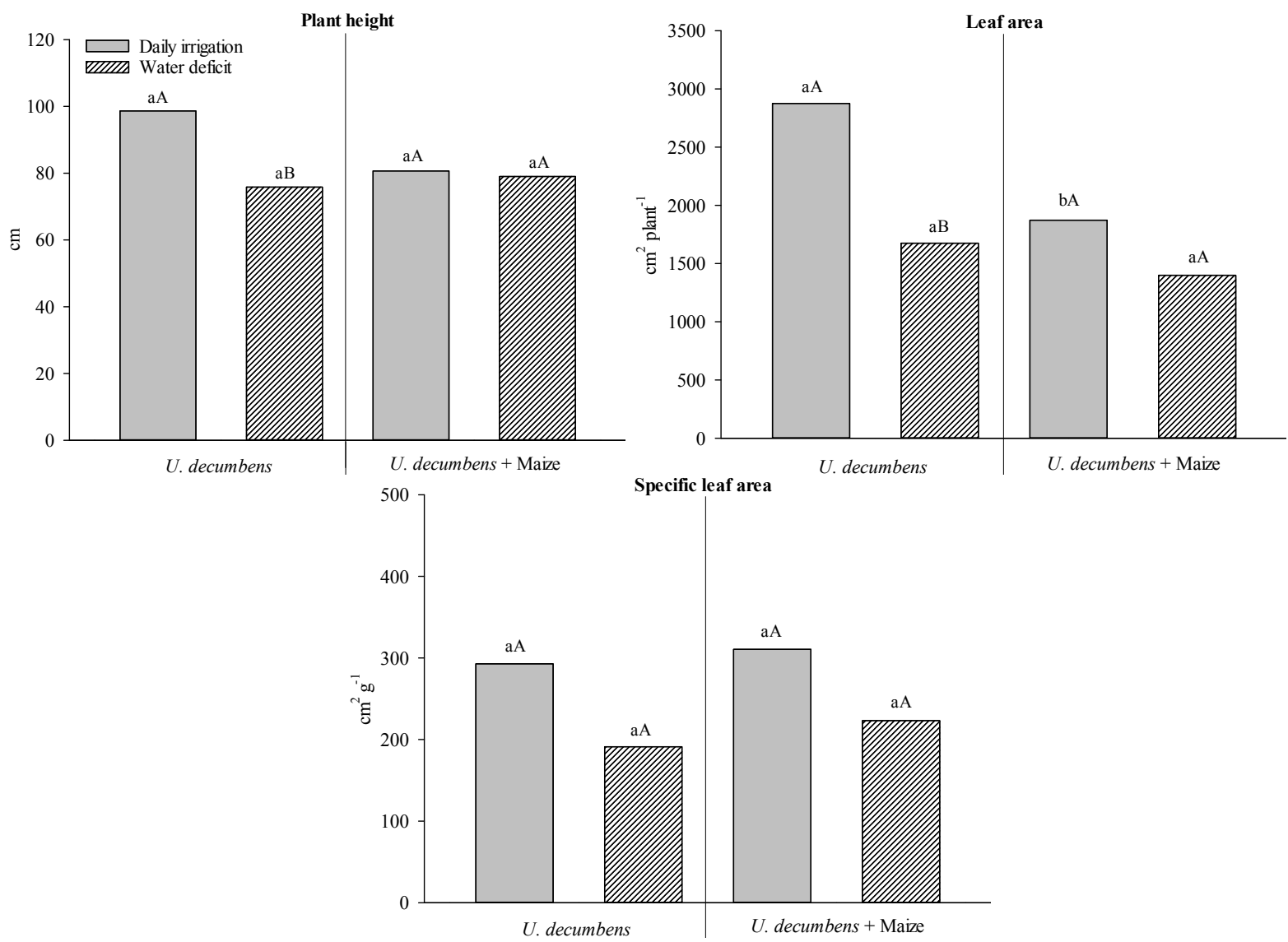

Figure 3. Plant height (PH), leaf area (LA) and specific leaf area (SLA) of $U$. decumbens in monoculture and competition with maize under water deficit or not. Different letters indicate difference ( $\mathrm{p} \leq 0.05$; Tukey's test): lowercase among types of arrangement between plants; upper case between the two water regimes.

Competition can often intensify the negative effects of water deficiency on plants (OLIVEIRA et al., 2018) However, this phenomenon did not occur in $U$. decumbens. The species had no alteration in $\mathrm{PH}, \mathrm{LA}$, and SLA when competing with maize under water deficit conditions. The efficient control of stomatal openings in $U$. decumbens plants may have contributed to maintain leaf turgescence, providing results that were similar to those found in the other evaluated treatments. In addition, it is possible that the composition of the cell wall aided the $U$. decumbens plants submitted to water deficiency and competition to maintain their LA similar to those grown in competition and under irrigated conditions. 
The lower elasticity of the cell wall allows the plant to maintain a larger LA even with a loss of turgor inside the cells (COSGROVE, 2015).

Another important consideration is that some grasses can extract water from the soil, even when there is little available, to maintain a minimal turgidity of their tissues (ZHOU et al., 2014). Thus, the association of water deficiency and competition may not have been adequate to reduce the amount of water in the soil to levels that could intensify the reduction of the LA of $U$. decumbens.

Maize competition reduced SDM and TDM for both the water availability and water deficiency conditions (Figure 4). It is likely that the erect growth habit of maize plants provoked strong competition for light and, because of their smaller size, $U$. decumbens plants were impaired. Under water deficit conditions, a reduction in stomatal expansion and stomatal closure possibly occurred, resulting in lower carbohydrate production accumulated as biomass (TAIZ et al., 2017). Despite the lower SDM and TDM of the $U$. decumbens plants in competition with maize, water deficiency did not intensify this decrease (Figure 4). U. decumbens was more aggressive in competition than that of maize, reducing the SDM and TDM of the plants more intensely. Therefore, under conditions of complex stress (competition + water deficiency) $U$. decumbens can maintain carbon fixation, reflecting the accumulation of similar dry mass in competition with maize, with or without water deficiency.

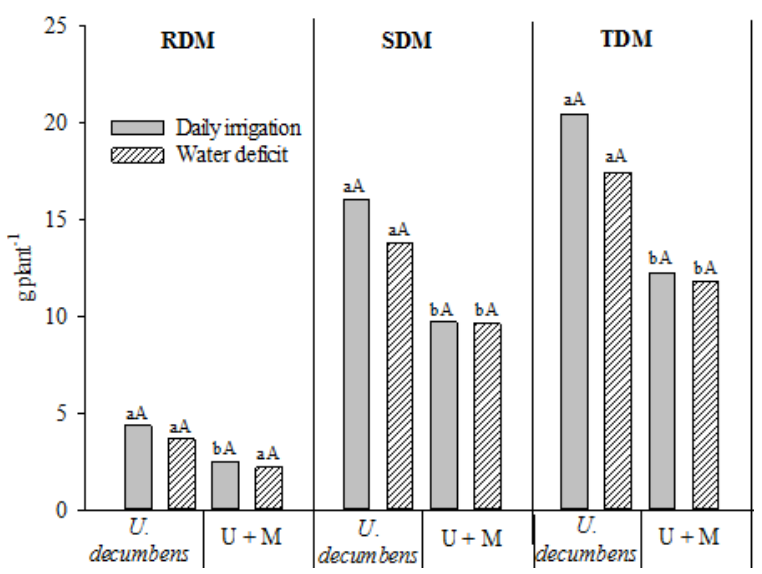

Figure 4. Root dry mass (RDM), shoot (SDM) and total (TDM) of $U$. decumbens in monoculture and competition with maize under water deficit or not. $\mathrm{M}=$ Maize; $\mathrm{U}=U$. decumbens. Different letters indicate difference $(\mathrm{p} \leq 0.05$; Tukey test): lowercase among types of arrangement between plants; upper case between the two water regimes.

Competition with maize decreased the RDM of plants only in the irrigation treatment (Figure 4). In some cases, the importance of competition for roots is more important under conditions of greater resource availability (SCHENK, 2006). Based on a study by Hutchings et al. (2003), the performance of individual plants in root competition depends largely on the size of the root systems, the distance between plants, and the fertility contrast between the soil regions near the roots. Therefore, the rapid initial growth of maize might have allowed the roots to occupy most of the soil volume, thus, hindering the growth of weed roots in the same place (MATOS et al., 2019).

\section{Growth of $B$. pilosa under conditions of water deficiency and competition with maize}

Water deficiency reduced the LA of B. pilosa only when cultivated in competition with maize (Figure 5). In addition, under the water deficit condition, competition with maize ensured lower LA of the plants compared to the treatment without competition. A reduction of LA is one of the first responses of plants under water deficient conditions. This is an important mechanism to reduce excessive water loss through transpiration and to prevent tissue dehydration (TAIZ et al., 2017). The PH and SLA of the plants were not influenced by water deficiency and/or maize competition. 


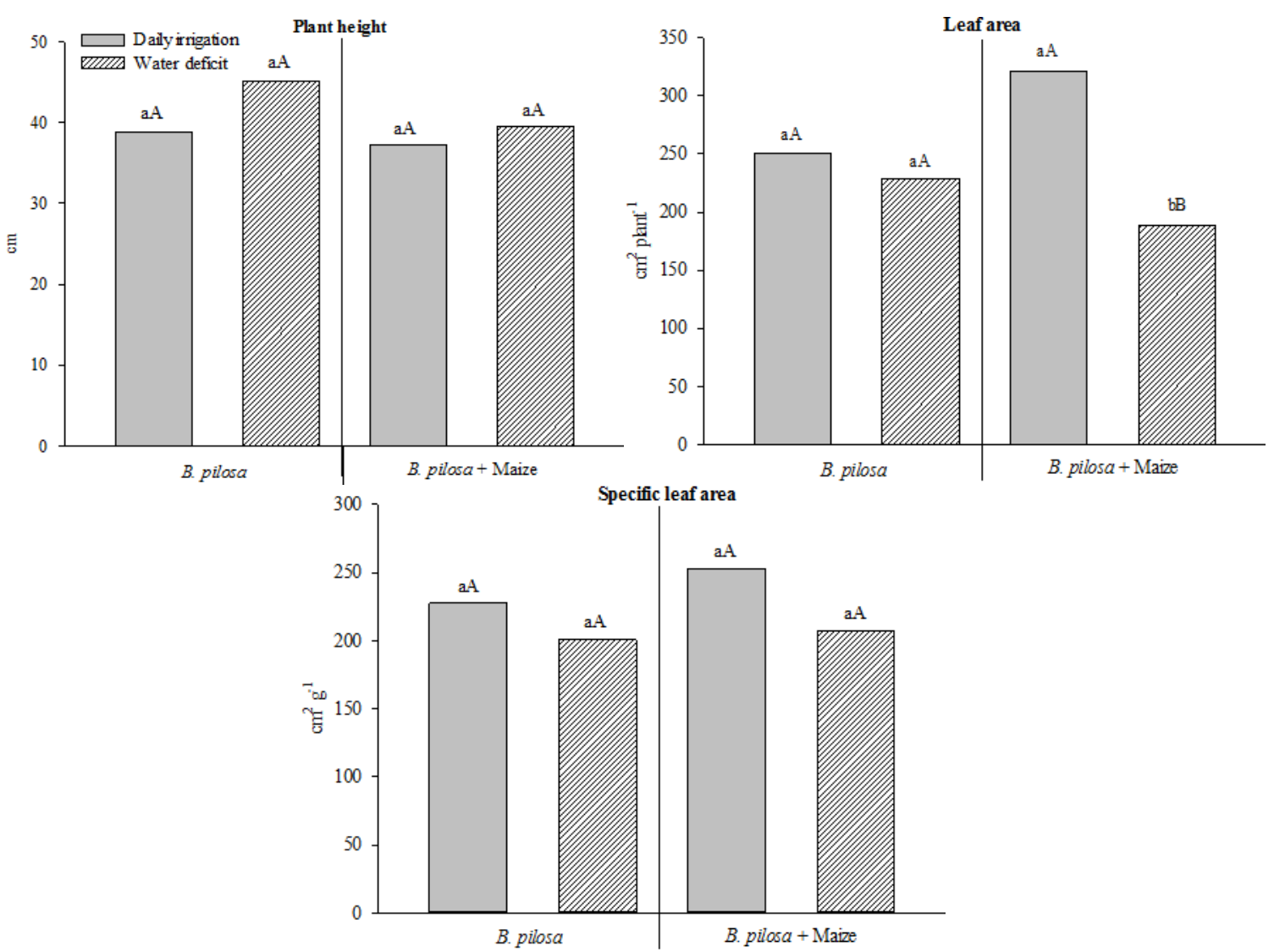

Figure 5. Plant height (PH), leaf area (LA) and specific leaf area (SLA) of B. pilosa in monoculture and competition with maize under water deficit or not. Different letters indicate difference ( $\mathrm{p} \leq 0.05$; Tukey's test): lowercase among types of arrangement between plants; upper case between the two water regimes.

Similar to PH and SLA, water deficiency and competition with maize had no noticeable effects on SDM, RDM, and TDM (Figure 6). This can be explained by $B$. pilosa having an investor strategy to survive water deficiency (OLIVEIRA et al., 2018).
This species can maintain its growth when extracting water at low levels of water potential in the soil, becoming an important competitor under low resource conditions (PROCÓPIO, 2004).

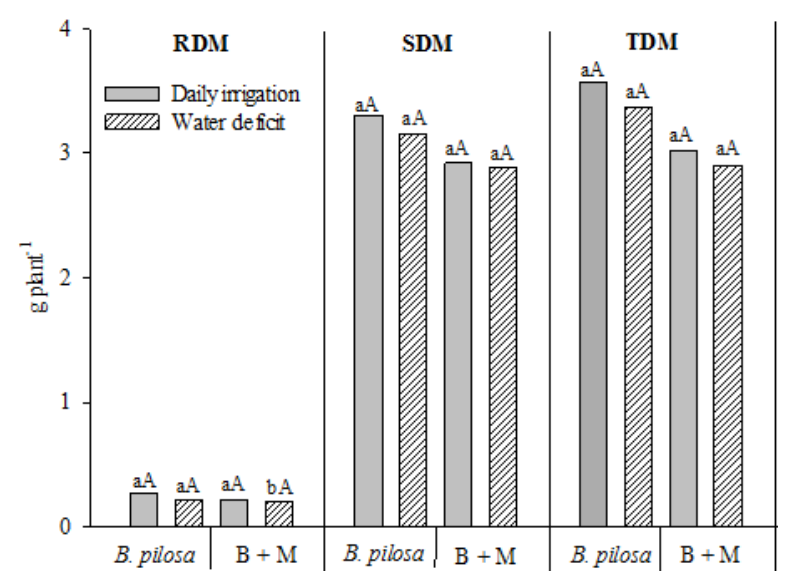

Figure 6. Root dry mass (RDM), shoot (SDM) and total (TDM) of B. pilosa in monoculture and competition with maize under water deficit or not. $\mathrm{B}=$ B. pilosa; $\mathrm{M}=$ Maize. Different letters indicate difference $(\mathrm{p} \leq 0.05$; Tukey test): lowercase among types of arrangement between plants; upper case between the two water regimes. 
Limitation of maize, $U$. decumbens, and $B$. pilosa growth under water deficiency and competition among plants

Interspecific competition aggravated the negative effects of water deficiency on maize plants and $U$. decumbens, leading to greater limitations of TDM in relation to other treatments (Table 2). Furthermore, under irrigated conditions, competition with maize was more detrimental to $U$. decumbens than it was to B. pilosa.

Table 2. Reduction of total dry mass (\%) of plants in competition and under water deficit, in relation to those grown in monoculture and daily irrigation.

\begin{tabular}{lcc}
\hline Trataments & Averages & Standard error \\
\hline B. pilosa + maize - Irrigated & $87.28 \mathrm{a}$ & $1.24 \pm$ \\
B. pilosa + maize - Water deficit & $83.89 \mathrm{a}$ & $1.14 \pm$ \\
Maize + B. pilosa - Irrigated & $81.09 \mathrm{a}$ & $1.54 \pm$ \\
Maize + U. decumbens - Irrigated & $69.59 \mathrm{a}$ & $1.40 \pm$ \\
U. decumbens + maize - Water deficit & $60.79 \mathrm{~b}$ & $1.24 \pm$ \\
Maize + B. pilosa - Water deficit & $56.02 \mathrm{~b}$ & $1.64 \pm$ \\
U. decumbens + maize - Irrigated & $55.53 \mathrm{~b}$ & $1.12 \pm$ \\
Maize + U. decumbens - Water deficit & $35.68 \mathrm{c}$ & $1.52 \pm$ \\
\hline
\end{tabular}

Averages followed by the same letter do not differ for each variable at the $5 \%$ probability level by the Tukey's test.

B. pilosa presented greater resistance to adverse conditions caused by competition and water deficiency (ASPIAZÚ et al., 2010). Although $B$. pilosa was harmed by competition with the crop, the species was able to make better use of the available water in the soil, demonstrating greater rusticity in relation to maize and $U$. decumbens (VASCONCELOS; SILVA, LIMA, 2012).

Despite the success of the maize- $U$. decumbens intercropping system (FERREIRA et al., 2014), the losses caused to $U$. decumbens and maize plants in situations of water scarcity, aggravated by the competition among these species, demonstrate the need to adopt practices that reduce the competitiveness during early growth periods, to save resources for crops to use. In the present study, we utilized the same density of weeds and crop culture. Thus, changes in spacing and density of plants in competition may cause different responses.

\section{CONCLUSIONS}

Soil water deficiency strongly reduced maize plant growth; however, there was little or no effect on the growth of the weeds $U$. decumbens and $B$. pilosa.

Interspecific competition reduced the growth of maize plants and $U$. decumbens, and intensified the negative effects of water deficiency in these species.

Interspecific competition and water deficiency also reduced $\mathrm{N}, \mathrm{P}$, and $\mathrm{K}$ contents in maize plants, which contributed to the effects on plant growth.

$U$. decumbens was more competitive with maize compared to $B$. pilosa.

\section{ACKNOWLEDGMENTS}

The present work was carried out with the support of the Coordination of Improvement of Higher Education Personnel - Brazil, Financing Code 001, and the research group of the Plant Engineering Department of the Federal Rural SemiArid University, which develop management technologies of weeds in semiarid areas.

\section{REFERENCES}

ASPIAZÚ, I. et al. Characteristics associated to photosynthesis and water use of weed species. Planta Daninha, v. 28, n. 1, p. 87-92, 2010.

BASU, S. et al. Plant adaptation to drought stress. F1000research, v. 5, n. 1, p.1554-1564, 2016.

CARVALHO, L. P. et al. Crescimento, teor de partenolídeo e de prolina em plantas de Tanacetum parthenium (L.) Shultz-Bip crescidas em substrato com diferentes teores de umidade. Acta Scientiarum. Agronomy, v. 27, n. 1, p. 151-157, 2005.

COSGROVE, D. J. Plant cell wall extensibility: connecting plant cell growth with cell wall structure, mechanics, and the action of wall-modifying enzymes. Journal of Experimental Botany, v. 67, n. 2, p. 463-476, 2015.

CUSTODIO, C. J. S. et al. Fatores que contribuíram para o crescimento da produtividade do milho no Brasil. Revista Eletrônica Interdisciplinar, v. 1, 
n. 15 , p. $174-179,2016$.

EMPRESA BRASILEIRA DE PESQUISA AGROPECUÁRIA - EMBRAPA. Sistema brasileiro de classificação de solos. 5 ed. Embrapa: Brasília, DF, Brasil. 531 p. 2018.

FENG, W. et al. Growing out of stress: The role of cell- and Organ-Scale Growth control in plant waterstress responses. The Plant Cell, v. 28, n. 8, p. 17691782, 2016.

FERREIRA, E. A. et al. Desempenho e uso eficiente da terra de modalidades de consorciação com milho e forrageiras. Revista Caatinga, v. 27, n. 3, p. 2229,2014

FLORINDO, J. B. et al. Brachiaria species identification using imaging techniques based on fractal descriptors. Computers and Electronics in Agriculture, v. 103, n. 1, p. 48-54, 2014.

FOTELLI, M. N. et al. Drought affects the competitive interactions between Fagus sylvatica seedlings and an early successional species, Rubus fruticosus: responses of growth, water status and delta13C composition. New Phytologist, v. 151, n. 2 , p. $427-435,2001$

GANTOLI, G.; AYALA, V. R.; GERHARDS, R. Determination of the critical period for weed control in corn. Weed Technology, v. 27, n. 1, p. 63-71, 2013.

GESSLER, A.; SCHAUB, M.; MCDOWELL, N. G. The role of nutrients in drought-induced tree mortality and recovery. New Phytologist, v. 214, n. 2 , p. $513-520,2017$.

GHANNOUM, O.; VON CAEMMERER, S.; CONROY, J. P. The effect of drought on plant water use efficiency of nine NAD-ME and nine NADP-ME Australian C4 grasses. Functional Plant Biology, v. 29, n. 11, p. 1337-1348, 2002.

GHEYSARI, M. et al. Comparison of deficit irrigation management strategies on root, plant growth and biomass productivity of silage maize. Agricultural Water Management, v. 182, n. 1, p. 126-138, 2017.

GUENNI, O.; BARUCH, Z.; MARIN, D. Responses to drought of five Brachiaria species. II. Water relations and leaf das exchange. Plant and Soil, v. 258, n. 1, p. 249-260, 2004.

HU, Y.; SCHMIDHALTER, U. Drought and salinity: A comparison of their effects on mineral nutrition of plants. Journal of Plant Nutrition and Soil Science, v. 168, n. 4, p. 541-549, 2005.
HUTCHINGS, M. J. et al. Toward understanding the consequences of soil heterogeneity for plant populations and communities. Ecology, v. 84, n. 9, p. 2322-2334, 2003.

KAUR, S.; KAUR, R.; CHAUHAN, B. S. Understanding crop-weed-fertilizer-water interactions and their implications for weed management in agricultural systems. Crop Protection, v. 103, n. 1, p. 65-72, 2018.

LIU, F.; STÜTZEL, H. Biomass partitioning, specific leaf area, and water use efficiency of vegetable amaranth (Amaranthus spp.) in response to drought stress. Scientia Horticulturae, v. 102, n. 1, p. 15-27, 2004

MALAVOLTA, E; VITTI, G. C.; OLIVEIRA, S. A. Avaliação do estado nutricional das plantas: princípios e aplicações. 2. ed. Piracicaba, SP: POTAFOS, 1997. 319p.

MARSCHNER, H. Mineral nutrition of higher plants. 2. ed. Londres, Academic Press, 1995. p. 347 $-364$.

MARWEIN, M. A. et al. Response of water deficit regime and soil amelioration on evapotranspiration loss and water use efficiency of maize (Zea mays L.) in subtropical northeastern Himalayas. International Journal of Biometeorology, v. 61, n. 5, p. 845-855, 2017.

MASHINGAIDZE, N. et al. Response of weed flora to conservation agriculture systems and weeding intensity in semi-arid Zimbabwe. African Journal of Agricultural Research, v. 7, n. 36, p. 5069-5082, 2012 .

MATOS, C. C. et al. Interspecific competition changes nutrient: nutrient ratios of weeds and maize. Journal of Plant Nutrition and Soil Science, v. 182, n. 2, p. 286-295, 2019.

NESMITH, D. S.; RITCHIE, J. T. Effects of soil water-deficits during tassel emergence on development and yield component of maize ( $\mathrm{Zea}$ mays). Field Crops Research, v. 28, n. 3, p. 251$256,1992$.

OLIVEIRA, F. S. et al. Competition between cowpea and weeds for water: Effect on plants growth. Revista Brasileira de Ciências Agrárias Brazilian Journal of Agricultural Sciences, v. 13, n. 1, p. 1-7, 2018.

PROCÓPIO, S. O. Ponto de murcha permanente de soja, feijão e plantas daninhas. Planta Daninha, v. 22 , n. 1, p. 35-41, 2004. 
RAJCAN, I.; SWANTON, C. J. Understanding maize-weed competition: resource competition, light quality and the whole plant. Field Crops Research, v. 71, n. 2, p. 139-150, 2001.

SALES, R. A. et al. Estimativas das necessidades hídricas do milho cultivado nas condições edafoclimáticas de São Mateus-ES. Enciclopédia Biosfera, v. 13, n. 23, p. 598-609, 2016.

SCHENK, H. J. Root competition: beyond resource depletion. Journal of Ecology, v. 94, n. 4, p. 725739, 2006.

SILVA, J. F. et al. Morfologia de milho safrinha em espaçamento reduzido e consorciado com Urochloa ruziziensis. Revista Agrarian, v. 6, n. 21, p. 259267, 2013.

SOUZA, M. S. et al. Comparação de métodos de mensuração de área foliar para a cultura da melancia. Pesquisa Agropecuária Tropical, v. 42, n. 2, p. 241 -245, 2012.

TAIZ, L. et al. Fisiologia e desenvolvimento vegetal. 6. ed. Porto Alegre, RS: Artmed, 2017. 888 p.

UNITED STATES DEPARTMENT OF AGRICULTURE - USDA. Safra Mundial de Milho 2016/17 - 11 $^{\circ}$ Levantamento do USDA. Informativo. Disponível em: <http:// www.fiesp.com.br/indices-pesquisas-e-103 publicacoes/safra-mundial-de-milho-2/>. Acesso em: 24 abr. 2017.

VASCONCELOS, M. C. C.; SILVA, A. F. A.; LIMA, R. S. Interferência de plantas daninhas sobre plantas cultivadas. Agropecuária Científica no Semiárido, v. 8, n. 1, p. 1-6, 2012.

WALKER, B. J. et al. The costs of photorespiration to food production now and in the future. Annual Review of Plant Biology, v. 67, n. 1, p. 107-129, 2016.

ZHOU, Y. et al. Drought resistance and soil water extraction of a perennial C4 grass: contributions of root and rhizome traits. Functional Plant Biology, v. 41, n. 5, p. 505-519, 2014. 